\title{
IMPROVING INDONESIAN WRITING ABILITY AND HOW TO WRITE THE VALUE OF MONEY WITH AUDIO VISUAL MEDIA AT SECOND GRADE STUDENTS OF SD NEGERI 28 PASAR GOMPONG KECAMATAN LENGAYANG
}

\author{
NURLIS
}

Volume 1 Nomor 1

JIPS ISSN: 2579-5449

\begin{abstract}
This classroom action research is motivated by several factors, including the lack of students' ability to write short stories. The problem in this research is how improve the students' ability to write stories Indonesian (BI) and ways of writing money by using audio-visual media.

This study aims to improve students' ability to write stories and ways of writing the value of money by using audio-visual media, writing back with their own words you've already watched the film becomes an example.

This study is a quantitative and qualitative. The method used in this research is the method of observation and tests. Setting this study in SDN 28 Gompong Market District of Lengayang, which is in Class II SD Negeri 28 Market

Gompong totaling 32 students. The process of execution of the actions carried out in two cycles, and each cycle consists of four stages from planning, action, observation and reflection stages.

The results of quantitative research in the first cycle with the results of 69\% (average grade) and 69\% (the number of students who pass the study). While on the second cycle showed an increase in $84 \%$ (average grade) and $100 \%$ (the number of students who pass the study). From this study it can be concluded that by using audio-visual media can improve the ability to write short stories and ways of writing the value of money Class II SD Negeri 28 Gompong Market.
\end{abstract}

Keywords : media audio visual 


\title{
MENINGKATKAN KEMAMPUAN MENULIS BAHASA INDONESIA \\ DAN CARA PENULISAN NILAI UANG DENGAN MEDIA AUDIO \\ VISUAL SISWA KELAS II SD NEGERI 28 PASAR GOMPONG KECAMATAN LENGAYANG
}

\begin{abstract}
ABSTRAK
Penelitian tindakan kelas ini dilatarbelakangi oleh beberapa faktor, antara lain kurangnya kemampuan murid dalam menulis cerpen. Permasalahan dalam penelitian ini adalah bagaimanakah meningkatkan kemampuan murid dalam menulis cerita Bahasa Indonesia (BI) dan cara penulisan uang dengan menggunakan media audio visual.

Penelitian ini bertujuan untuk meningkatkan kemampuan murid dalam menulis cerita dan cara penulisan nilai uang dengan menggunakan media audio visual, yaitu dengan menulis kembali dengan kata-kata sendiri film yang sudah ditonton menjadi sebuah contoh.

Penelitian ini bersifat kuantitatif dan kualitatif. Metode yang digunakan dalam penelitian ini adalah metode observasi dan tes. Setting penelitian ini di SD Negeri 28 Pasar

Gompong Kecamatan Lengayang, yaitu di Kelas II SD Negeri 28 Pasar Gompong yang berjumlah 32 orang murid. Proses pelaksanaaan tindakan dilakukan dalam dua siklus, dan tiap siklus terdiri atas empat tahap yaitu mulai dari tahap perencanaan, pelaksanaan tindakan, observasi, dan tahap refleksi.

Hasil penelitian secara kuantitatif pada siklus I dengan hasil 69\% (rata-rata kelas) dan $69 \%$ (jumlah murid yang tuntas belajar). Sedangkan pada siklus II menunjukkan peningkatan $84 \%$ (rata-rata kelas) dan $100 \%$ (jumlah siswa yang tuntas belajar). Dari penelitian ini dapat diambil kesimpulan bahwa dengan menggunakan media audio visual dapat meningkatkan kemampuan menulis cerpen dan cara penulisan nilai uang Kelas II SD Negeri 28 Pasar Gompong.
\end{abstract}

Kata Kunci : media, audio, visual

\section{PENDAhuluan}

Latar Belakang, Saat ini pendidikan dan pembelajaran mengalami penyempurnaan baik dari segi kurikulum, metode maupun media pembelajaran yang diterapkan dalam proses belajar mengajar. Salah satunya yaitu dengan digunakannya Kurikulun Tingkat Satuan Pembelajaran (KTSP). Pelaksanaan KTSP membutuhkan guru yang profesional dan kreatif dalam proses belajar mengajar, yaitu menggunakan metode, teknik dan media yang bervariasi sehingga membangkitkan motivasi siswa untuk belajar. Sebagai keterampilan produktif, menulis dan berhitung menghendaki siswa untuk mampu menggali, menemukan, dan mengungkapkan gagasannya, perasaan, pengalaman, serta penggunaan bahasa yang tepat.

Namun, pada kenyataannya tidak semua siswa dapat menunjukkan kemampuan tersebut. Di dalam menulis, dan berhitung siswa merasakan kurangnya keyakinan, minat, dan latihan yang memadai untuk menulis. Mengingat pentingnya menulis bagi siswa, guru semestinya bisa membangkitkan kegairahan siswa menulis serta menjadikan menulis itu merur 189 pekerjaan yang alami dan menyenan 
Langkah utama yang bisa ditempuh adalah dengan memilih dan menggunakan metode dan media pembelajaran yang tepat dan variatif yaitu dengan menggunakan media audio visual yang dapat membantu mengatasi keterbatasan ruang, waktu dan daya indera, karena menurut para ahli kemampuan daya serap manusia dalam memahami masalah dengan panca indera yaitu ; telinga (pendengaran) 13\%, mata (penglihatan) $75 \%$, hidung (penciuman) 3\%, kulit 6\%, lidah (rasa) 3\%. Penggunaan media audio visual ditujukan untuk meningkatkan efektifitas dan efisiensi proses belajar mengajar, sehingga diharapkan siswa mampu mengembangkan daya nalar serta daya rekanya.

Penggunaan media tersebut sangat perlu mengingat permasalahan yang ditemukan pada Sekolah Dasar yaitu masih kurangnya kemampuan siswa dalam menulis. Faktor yang menimbulkan munculnya masalah ini antara lain, siswa merasa kurang bersemangat dalam menggunakan nalarnya, karena kurangnya latihan menulis, sehingga siswa tidak terbiasa dalam menulis. Disinilah letak kesulitannya, siswa merasa kesulitan untuk menuangkan maksud, pikiran, gagasan maupun imajinasinya dalam sebuah karangan.

Rumusan masalah dalam penelitian ini adalah "Bagaimanakah meningkatkan kemampuan siswa menulis cerita (BI) dan penulisan nilai uang dengan media audio visual murid Kelas II semester ganjil SD Negeri 28 Pasar Gompong Kecamatan Lengayang?

Pemecahan Masalah kurangnya kemampuan murid Kelas II SD Negeri 28 Pasar Gompong Kecamatan Lengayang dalam menulis cerita dan menulis nilai uang dapat diminimalkan dengan menggunakan media audio visual, yakni dengan memutar film yang nantinya siswa disuruh menulis kembali dengan kata-kata sendiri dalam bentuk cerpen tulisan sebgaimana yang ditonton tersebut.

Penelitian ini bertujuan untuk meningkatkan kemampuan siswa menulis cerita dan menulis nilai uang dengan media audio visual murid Kelas II Semester Ganjil SD Negeri 28 Pasar Gompong Kecamatan Lengayang.

\section{METODE PENELITIAN}

Penelitian ini merupakan penelitian tindakan kelas yang dilakukan untuk meningkatkan kemampuan siswa dalam pembelajaran bahasa, khususnya dalam menulis mata pelajaran bahasa Indonesia. Adapun tindakan yang dilakukan adalah dengan menggunakan media audio visual, yakni dengan memutarkan sebuah film kemudian siswa menulis kembali secara kronologis alur film tersebut dalam bentuk cerita pendek.

Seting penelitian Penelitian tindakan kelas tentang: "Meningkatkan Kemampuan Menulis (BI) dan cara penulisan nilai uang dengan Media Audio Visual" ini dilakukan di murid Kelas II SD Negeri 28 Pasar Gompong Kecamatan Lengayang pada semester 1.". Subjek penelitian ini adalah siswa kelas murid Kelas II SD Negeri 28 Pasar Gompong Kecamatan Lengayang dengan jumlah siswa 32 orang.
Sebelum melakukan penelitian, peneliti melakukan observasi awal untuk mengetahui kemampuan siswa dalam menulis cerpen dengan menyuruh siswa menulis cerpen dengan tema bebas, dari observasi ini diketahui dari 32 siswa tersebut masih memiliki kemampuan menulis cerpen yang rendah terutama kesulitan dalam menuangan ide dan gagasannya dalam sebuah tulisan.

Rancangan Penelitian, 1) Merancang atau membuat lembar observasi yang digunakan sebagai petunjuk untuk mengamati proses kegiatan pembelajaran dan mengidentifikasi faktor penghambat yang dihadapi oleh siswa dalam menulis cerita pendek. 2) Menyusun rencana tindakan berupa model rencana pembelajaran. Rencana pembelajaran disusun dengan memperhatikan hal-hal sebagai berikut: (1) menetapkan indikator pembelajaran menulis cerita pendek, (memilih dan menetapkan yang akan disajikan), (2) menyediakan 
pembelajaran yang akan digunakan (komputer, LCD, dan CD film), dan (3) merencakan penilaian pembelajaran menulis cerpen. 4) Menyusun rencana pelaksanaan pembelajaran dengan menggunakan media audio visual. Pertemuan pertama dipokuskan pada pembelajaran menulis cerita pendek, yaitu menulis kembali dengan kata-kata sendiri film yang sudah ditonton. Sedangkan pertemuan kedua dipokuskan pada pemantapan dalam menulis cerita pendek, yaitu dengan mengoreksi hasil latihan siswa dalam menulis cerpen.

Pada tahap pelaksanaan tindakan ini rencana pelaksanaan pembelajaran yang telah disusun mulai dilaksanakan secara bertahap terdiri dari pendahuluan, kegiatan inti, dan penutup.

Agar pelaksanaan tindakan berjalan sesuai dengan rencana. Maka peneliti melakukan observasi sebagai bahan pertimbangan untuk evaluasi lebih lanjut pada pelaksanaan tindakan. Observasi dilakukan untuk memperoleh data, yaitu data hasil kerja siswa dan data proses kerja siswa. Data hasil dalam penelitian ini adalah berupa hasil kerja siswa pada setiap tahap pembelajaran menulis cerpen dengan media audio visual. Data tersebut diperoleh dengan menggunakan panduan penilaian kemampuan siswa dalam menulis kembali film yang sudah ditonton menjadi sebuah cerpen sesuai dengan alur film tersebut. Sedangkan data proses diperoleh melalui kegiatan pengamatan pembelajaran menulis cerpen yang dilakukan oleh peneliti.

Berdasarkan hasil yang diperoleh pada tahap observasi tindakan kelas, maka peneliti selanjutnya melakukan analisis hasil observasi dan menyimpulkan data yang diperoleh serta melihat hubungan dengan rencana yang telah ditetapkan. Analisis dan interpretasi hasil tindakan selanjutnya menjadi dasar untuk melakukan evaluasi dalam menentukan keberhasilan atau pencapaian tujuan tindakan.

Kesimpulan hasil evaluasi menjadi acuan dalam mengambil keputusan tindakan, apakah tindakan telah berhasil ataukah belum sesuai dengan kriteria keberhasilan sehingga dilakukan perubahan atau revisi terhadap rencana dan pelaksanaan tindakan pada siklus berikutnya sampai target tercapai.

Sumber data dalam penelitian ini adalah lembar kerja siswa dan proses kerja siswa yang diperoleh melalui pengamatan siswa kelas murid Kelas II SD Negeri 28 Pasar Gompong Kecamatan Lengayang yang berjumlah 32 orang. (Lembar Kerja Siswa terlampir).

Jenis data yang diperoleh adalah data kuantitatif dan kualitatif yang terdiri atas: (1) rencana pelaksanaan pembelajaran, (2) hasil pembelajaran siswa, (3) hasil observasi selama kegiatan pembelajaran yang menunjukkan peningkatan kemampuan siswa dalam menulis cerita dan cara penulisan mata uang.

Pengambilan data dilakukan dengan cara sebagai berikut: a) Data hasil pembelajaran diambil dengan latihan pada siswa menggunakan media audio visual, dengan menyimak film kemudian siswa menulis kembali dengan kata-kata sendiri film yang sudah ditonton. b) Data situasi pembelajaran diambil dengan menggunakan lembar observasi. b) Data perkembangan prestasi belajar siswa diambil dari hasil pembelajaran dan hasil observasi.

Analisis data dilakukan dengan menggunakan rumus sebagai berikut: 1) Mencari prosentasi nilai rata-rata keseluruhan (klasikal) Rumus:

$$
\mathrm{x}^{-}=\frac{\sum \mathrm{f}(\mathrm{x})}{\mathrm{n}}
$$

Keterangan:

$$
\begin{array}{ll}
\mathrm{x}^{-} & =\text {Mean atau rata-rata } \\
\Sigma \mathrm{f}(\mathrm{x}) & =\text { Jumlah seluruh skor (nilai seluruh siswa) } \\
\mathrm{n} & =\text { Jumlah siswa }
\end{array}
$$

Mencari prosentasi jumlah siswa yang mendapat nilai standar minimal ke atas dengan rumus: Ketuntasan belajar $($ klasikal $)=$ Qr $\times 100 \%$ 
Keterangan:

Qr = Jumlah siswa yang tuntas belajar

$\mathrm{T}=$ Jumlah seluruh siswa

Indikator kinerja tolak ukur keberhasilan penelitian ini adalah apabila pembelajaran dengan menggunakan media audio visual mampu meningkatkan kemampuan siswa dalam membuat cerita pendek (cerpen) di atas $75 \%$ secara klasikal dan memperoleh hasil dengan kriteria baik (65) berdasarkan standar ketuntasan belajar minimal maka pembelajaran dianggap berhasil. Sedangkan dalam proses pembelajaran dapat dilihat pada aspek; siswa lebih termotivasi, adanya perubahan sikap dari pasif menjadi aktif dalam proses pembelajaran, dan suasana kelas menjadi kondusif dan menyenangkan.

\section{HASIL PENELITIAN DAN PEMBAHASAN}

Pada tahap perencanaan tindakan ini, peneliti melakukan observasi mengenai faktorfaktor penghambat yang ditemui oleh siswa selama proses pembelajaran sebelum melaksanakan siklus I, agar peneliti dapat merumuskan alternatif tindakan. Adapaun faktorfaktor penghambat tersebut adalah: 1) Masih kurangnya pengetahuan siswa dalam menulis cerita pendek. 2) Dalam proses belajar mengajar guru menggunaan metode dan media yang kurang bervariasi sehingga siswa kurang termotivasi pada saat berlangsungnya menulis cerita pendek. 3) Siswa kurang aktif dalam proses pembelajaran, siswa hanya merespon atau bertanya jika ditunjuk oleh guru. 5) Kurangnya praktek atau latihan menulis yang diberikan, karena guru lebih menekankan pada teori. 5) Penataan bangku di kelas masih klasikal yaitu dengan berderet menyebabkan kebosanan.

Berdasarkan hasil pengamatan tersebut, dapat dirumuskan alternatif tindakan untuk meningkatkan kemampuan siswa pada siklus I, yaitu: 1) Menentukan strategi pembelajaran yang tepat. 2) Merumuskan rencana pelaksanaan pembelajaran. 3) Menyediakan alat bantu atau media pembelajaran. 4) Merancang soal penilaian hasil yang sesuai dengan standar kompetensi.

Dalam pelaksanaan tindakan ini, peneliti melaksanakan kegiatan pembelajan sesuai dengan rancangan pelaksanaan pembelajan yang telah disusun untuk meningkatkan kemampuan menulis cerita pendek dengan menggunakan media audio visual. Pelaksanaan siklus I dilakukan dengan menulis kembali dengan katakata sendiri film yang sudah ditonton dalam bentuk cerita pendek. Adapun hasil belajar siswa dalam menulis cerita pendek dengan menggunakan media audio visual murid Kelas II SD Negeri 28 Pasar Gompong Kecamatan Lengayang

Keterangan: $\mathrm{I}=$ Kesesuaian isi cerpen dengan film III = Penggunaan Kalimat Efektif IV = Penggunaam bahasa yang menarik $\mathrm{V}$ = Pemakaian tanda baca VI = Pemakain Huruf Besar.

Berdasarkan nilai di atas dideskripsikan ketuntasan belajar siswa pada masing-masing aspek ketuntasan dalam membuat cerpen.

Aspek pertama (kesesuaian isi cerpen siswa dengan alur film). Jumlah siswa yang memenuhi kriteria nilai tuntas sebanyak 31 siswa dengan nilai 25 (cerpen sangat sesuai dengan isi film) sebanyak 19 siswa atau 59,37\%, 12 siswa atau $37,5 \%$ mendapat nilai 20 (cerpen sesuai dengan isi film) dan 1 siswa atau 3,12\% yang tidak memenuhi kriteria nilai tuntas mendapat nilai 15 (cerpen kurang sesuai dengan isi film).

Aspek kedua (koherensi). Jumlah siswa yang memenuhi kriteria nilai tuntas sebanyak 29 siswa dengan nilai 15 (kalimat yang membangun cerpen sangat padu) sebanyak 4 siswa atau $12,5 \%, 25$ siswa atau 78,12\% mendapat nil $\sim$ : 1 n (kalimat yang membangun cerpen ditulis de 192 padu) dan 3 siswa atau 9,37\% yang memenuhi kriteria nilai tuntas mendapat nilai 7,5 (kalimat yang membangun cerpen di tulis kurang padu). 
Aspek ketiga (kalimat efektif). Jumlah siswa yang memenuhi kriteria nilai tuntas sebanyak 13 siswa atau $40,62 \%$ dengan nilai 10 (kalimat di susun dengan efektif) dan 19 siswa atau 59,37\% tidak memenuhi kriteria nilai tuntas mendapat nilai 7,5 (kalimat disusun kurang efektif).

Aspek keempat (penggunaan bahasa yang menarik). Jumlah siswa yang memenuhi kriteria nilai tuntas sebanyak 29 siswa dengan nilai 15 (bahasa yang digunakan sangat mudah dimengerti atau menarik) sebanyak 5 siswa atau $15,62 \%, 24$ siswa atau $75 \%$ mendapat nilai 10 (bahasa yang digunakan mudah dimengerti atau menarik), dan 3 siswa atau 9,37\% tidak memenuhi kriteria nilai tuntas dengan nilai 7,5 (bahasa yang digunakan kurang menarik).

Aspek kelima (pemakaian tanda baca). jumlah siswa yang memenuhi kriteria nilai tuntas sebanyak 7 siswa atau $21,87 \%$ dengan nilai 10 (pemakaian tanda baca tepat) dan 25 siswa atau $78,12 \%$ tidak memenuhi kriteria nilai tuntas dengan nilai 7,5 ( tanda baca kurang tepat).

Aspek keenam (pemakaian huruf kapital). Jumlah siswa yang memenuhi kriteria nilai tuntas sebanyak 11 siswa atau $34,37 \%$ dengan nilai 10 (pemakaian huruf kapital dengan tepat) dan 21 siswa atau $65,62 \%$ tidak memenuhi kriteria nilai tuntas dengan nilai 7,5 (pemakain huruf kapital kurang tepat).

Berdasarkan tabel nilai di atas, maka dapat diklasifikasikan tiap-tiap nilai atau skor yang dicapai oleh siswa berdasarkan kriteria yang sudah dijelaskan pada Bab III. Adapun skor tertinggi yang diperoleh siswa yang dikategorikan sangat baik (80-100) sebanyak 5 orang. Siswa yang mendapat nilai 66-79 dikategorikan baik sebanyak 15 orang. Siswa yang mendapat nilai 56-65 dikategorikan cukup baik berjumlah 11 orang dan 1 siswa dikategorikan kurang dengan nilai 52,5 yang bernama Ferawati.

Lima siswa di atas dikategorikan sangat baik (80-100) karena sudah mampu menulis cerpen dengan runtut sesuai dengan alur cerita film yang sudah ditayangkan. Alur cerita dirangkai dengan menggunakan kata-kata yang mudah dimengerti sehingga terjalin sebuah kalimat yang kompak atau padu, sedangkan untuk tanda baca dan huruf besar umumnya siswa sudah mampu menempatkannya dalam karangan bahwa nilai siswa dikategorikan baik (66-79) karena siswa umumnya sudah mampu menulis cerpen dengan runtut sesuai dengan isi film, tetapi masih kurang dalam pemakaian huruf besar dan tanda baca. Penggunaan tanda baca sering terjadi kekeliruan khususnya tanda koma dan tanda titik. Kekeliruan penempatan tanda koma biasanya terjadi pada penulisan kalimat majemuk setara yang dihubungkan dengan kata penghubung yang menyatakan perbandingan. Sedangkan pemakaian tanda titik kadang tidak terlalu diperhatikan penulisannya di akhir kalimat.

Nilai siswa dikategorikan cukup (56-65) karena siswa sudah mampu menulis cerpen dengan runtut walaupun tidak selengkap isi film yang sudah ditonton. Dalam karangan siswa masih banyak ditemukan penggunaan kata hubung yang berlebihan sehingga kalimatnya tidak efektif. Sedangkan dalam penggunaan tanda baca dan huruf besar, siswa masih kesulitan. Misalnya untuk menulis nama orang, siswa menggunakan huruf kecil pada awal kata unsur-unsur nama orang, begitu juga di awal kalimat.

Nilai siswa yang bernama Ferawati dikategorikan kurang $(52,5)$ karena cerpen yang dibuat hanya dua faragraf yang memuat sebagian kecil dari alur film, sedangkan kalimat yang dikembangkan kurang padu. Siswa juga kesulitan dalam memilih kata-kata dan sering mengulang menulis kata tersebut sehingga kalimat yang digunakan tidak efektif. Dalam penggunaan tanda baca dan huruf kapital, siswa masih kesulitan dalam pemakaiannya. Misalnya tanda titik kesulitan peletakannya di akhir kalimat untuk memisahkan kalimat yang satu dengan yang lainnya.

Dari kegiatan dan hasil belajar siswa menunjukkan hasil yang kurang maksimal walaupun siswa telah memenuhi standar kelulusan belajar mengajar mata pela:-..... Bahasa Indonesia di murid Kelas II SD N 193 28 Pasar Gompong Kecamatan Lenga dengan nilai 65 berdasarkan standar ketuntasan belajar minimal, tetapi belum memenuhi kriteria baik di atas $75 \%$ sehingga perlu dilakukan 
perbaikan lebih lanjut untuk memperbaiki keterampilan siswa menulis cerpen.

Berdasarkan observasi yang dilakukan peneliti didapatkan kesimpulan bahwa dalam siklus I siswa terlihat senang dan termotivasi dalam belajar karena sebelum menulis cepen siswa menonton film dengan menggunakan media komputer dan LCD, media tersebut membantu siswa mengkonkritkan ide-ide yang akan dituangkan dalam bentuk cerpen. Adapun kesulitan yang ditemui siswa yaitu dalam penulisan huruf kapital, tanda baca dan penempatan kata hubung untuk menghubungkan kalimat yang satu dengan yang lainnya sehingga masih banyak ditemukan dalam tulisan siswa kalimat yang tidak efektif. Oleh karena itu, perlu dilakukan pembelajaran ulang yaitu pada siklus II.

Berdasarkan hasil analisis data dalam pelaksanaan tindakan siklus I, diperoleh prosentase 68,90 atau $69 \%$ untuk nilai-nilai ratarata klasikal dan 68,75 atau $69 \%$ untuk jumlah siswa yang tuntas belajar. Hal ini menunjukkan bahwa hasil penilaian pada siklus I, murid Kelas II SD Negeri 28 Pasar Gompong Kecamatan Lengayang berjumlah 32 orang dapat dikategorikan belum berhasil karena hanya 22 orang yang tuntas belajar berdasarkan ketuntasan belajar minimal. Oleh sebab itu, penelitian harus dilanjutkan pada siklus II. Hal terbebut dimaksudkan agar dapat mencapai target yang diinginkan sesuai dengan indikator penilaian.

Ditinjau dari hasil observasi dan hasil pembelajaran siswa pada siklus sebelumnya, maka dapat dirumuskan alternatif tindakan sebagai upaya meningkatkan kemampuan siswa dalam menulis cerpen, antara lain sebagai berikut: a) Melaksanakan rencana pembelajaran lebih efektif dan terarah pada siswa yang masih perlu dapat bimbingan agar lebih baik dari siklus sebelumnya. b) Rencana pembelajaran lebih terfokus pada penyederhanaan kalimat-kalimat, pemakaian huruf kapital, dan tanda baca. c) Membagikan siswa ringkasan materi penulisan huruf kapital dan tanda baca. d) Menyediakan media yang sama pada siklus I, yaitu melanjutkan kelanjutan film pada siklus I dengan memutar disc kedua.
Berdasarkan hasil tindakan dan observasi pada siklus I yang menunjukkan hasil yang masih kurang, maka perlu dilakukan perbaikan untuk mencapai yang diharapkan yaitu dapat meningkatkan kemampuan menulis cerpen di atas $75 \%$ sehingga penelitian dilanjutkan dengan siklus II. Dengan demikian, pelaksanaan tindakan siklus II akan lebih difokuskan pada beberapa siswa yang masih mengalami kesulitan dalam menulis cerpen dengan menggunakan media audio visual, yaitu memutarkan lanjutan film pada siklus pertama (disc 2).

Berdasarkan hal tersebut, maka peneliti dapat merumuskan tindakan upaya meningkatkan kemampuan siswa dalam siklus II, yaitu: a) Menyusun rencana pelaksanaan pembelajaran yang efektif dan terarah pada siswa yang masih perlu dapat bimbingan agar lebih baik dari siklus sebelumnya. b) Rencana pembelajaran lebih terfokus pada penyederhanaan kalimat-kalimat, tanda baca dan penggunaan huruf kapital. b) Membagikan setiap siswa ringkasan materi tentang penggunaan huruf kapital. c) Lebih memotivasi dan mengadakan pendekatanpendekatan dengan siswa sehingga siswa merasa diperhatikan. d) Memberikan hadiah bagi siswa yang terbaik hasilnya Memberikan lembar kerja siswa pada tiap-tiap siswa

Pelaksanaan tindakan siklus II hampir sama dengan siklus I. Namun, kegiatan pembelajaran pada siklus II lebih menitikberatakan pada penguasaan materi tentang menulis cerpen dengan memperhatikan penggunaan bahasa yang menarik, penggunaan kalimat efektif, ketepatan penggunaan tanda baca serta kesesuaian isi cerpen dengan film yang sudah ditayangkan. Adapun hasil pembelajaran siswa dalam menulis cerpen dengan menggunakan audio visual di murid Kelas II SD Negeri 28 Pasar Gompong Kecamatan Lengayang.

Berdasarkan nilai di atas dideskripsikan ketuntasan belajar siswa pada masing-m ${ }^{-\infty}$ aspek ketuntasan dalam membuat cerpen.

Aspek pertama (kesesuaian isi c siswa dengan alur film). Jumlah siswa yang memenuhi kriteria nilai tuntas sebanyak 32 siswa dengan nilai 25 (cerpen sangat sesuai dengan isi film) sebanyak 29 siswa atau 90,62\% dan 3 
siswa atau 9,37\% mendapat nilai 20 (cerpen sesuai dengan isi film).

Aspek kedua (koherensi). Jumlah siswa yang memenuhi kriteria nilai tuntas sebanyak 32 siswa dengan nilai 15 (kalimat yang membangun cerpen sangat padu) sebanyak 9 siswa atau $28,12 \%$ dan 23 siswa atau $71,97 \%$ mendapat nilai 10 (kalimat yang membangun cerpen ditulis dengan padu).

Aspek ketiga (kalimat efektif). Jumlah siswa yang memenuhi kriteria nilai tuntas sebanyak 32 siswa dengan nilai 15 (kalimat disusun dengan sangat efektif) sebanyak 5 siswa atau $15,62 \%$ dan 27 siswa atau 84,37\% mendapat nilai 10 (kalimat disusun dengan efektif).

Aspek keempat (penggunaan bahasa yang menarik). Jumlah siswa yang memenuhi kriteria nilai tuntas sebanyak 32 siswa dengan nilai 15 (bahasa yang digunakan sangat mudah dimengerti atau menarik) sebanyak 22 siswa atau $68,79 \%$ dan 10 siswa atau $31,25 \%$ mendapat nilai 10 (bahasa yang digunakan mudah dimengerti atau menarik).

Aspek kelima (pemakaian tanda baca). jumlah siswa yang memenuhi kriteria nilai tuntas sebanyak 27 siswa atau $84,37 \%$ dengan nilai 10 (pemakaian tanda baca dengan tepat) dan 5 siswa atau $15,62 \%$ belum memenuhi kriteria nilai tuntas dengan nilai 7,5 (pemakain tanda baca kurang tepat).

Aspek keenam (pemakaian huruf kapital). Jumlah siswa yang memenuhi kriteria nilai tuntas sebanyak 31 siswa atau $98,87 \%$ dengan nilai 15 (pemakaian huruf kapital dengan sangat tepat) sebanyak 10 siswa atau 31,25\%, 21 siswa atau $65,62 \%$ mendapat nilai 10 (pemakain huruf kapital dengan tepat) dan 1 siswa atau 3,12\% belum memenuhi kriteria nilai tuntas dengan nilai 7,5 (pemakain huruf kapital kurang tepat).

Berdasarkan hasil pembelajaran siswa pada tahap pelaksanaan tindakan siklus II di atas, dapat dijelaskan dengan indikator penilain yakni; siswa yang mendapatkan kategori baik sekali (80-100) sebanyak 20 orang, siswa yang mendapat nilai 66-79 dikategorikan dengan baik sebanyak 12 orang, sedangkan nilai siswa yang kurang tidak ada.

Dari observasi hasil belajar siswa pada siklus II, maka pembelajaran dengan media audio visual dapat meningkatkan kemampuan siswa dalam menulis cerpen dengan nilai rata-rata klasikal 81,25 atau $81 \%$ dan $100 \%$ untuk jumlah siswa yang tuntas belajar. Hal tersebut disebabkan oleh pemahaman siswa yang makin mendalam mengenai penulisan cerpen, baik dalam penulisan huruf kapital, pengolahan kata maupun penulisan kalimatnya. Sedangkan dilihat dari dari proses belajar mengajar, siswa lebih aktif dan lebih semangat dalam belajarnya.

Berdasarkan hasil penelitian pada siklus II, penelitian ini dikatakan berhasil sehingga tidak perlu dilakukan perbaikan pada siklus berikutnya. Ditinjau dari hasil analisis data dan observasi dalam tahap pelaksanaan tindakan siklus II, diperoleh data sebagai berikut:

Kemampuan siswa dalam menulis cepen dengan media audio visual menunjukkan peningkatan yang maksimal, yaitu mencapai 81,25 atau $81 \%$ untuk pencapaian rata-rata klasikal dan $100 \%$ untuk siswa yang tuntas belajar.

Meningkatnya kemampuan siswa menggunakan huruf kapital yaitu mencapai $98,87 \%$, tanda baca mencapai $84,37 \%$, dan kalimat efektif mencapai $100 \%$. Rencana pelaksanaan pembelajaran yang disusun sudah mencapai tujuan. Siswa lebih aktif dan bergairah dalam belajar Suasana kelas lebih kondusif dan menyenangkan. Dengan memperhatikan hasil belajar siswa pada siklus II, maka pembelajaran dengan media audio visual dapat meningkatkan kemampuan siswa menulis cerpen. Dengan demikian, penelitian ini tidak akan dilanjutkan ke siklus berikutnya.

Dengan demikian penelitian ini dapat menjawab permasalahan mengenai peningkatan kemampuan siswa dalam menulis cerpen dengan media audio visual murid Kelas II SD Negeri 28 Pasar Gompong Kecamatan Lengayang.
195

\section{KESIMPULAN DAN SARAN}


Dari pembahasan hasil penelitian yang telah dilakukan dapat disimpulkan bahwa penggunaan media audio visual sebagai salah satu media pembelajaran Bahasa Indonesia dapat meningkatkan kemampuan murid Kelas II SD Negeri 28 Pasar Gompong Kecamatan Lengayang.

Hal tersebut dapat dilihat dari peningkatan kemampuan siswa pada siklus I dan siklus II, yaitu : 1) Pada siklus I, kemampuan siswa dalam menulis cerpen dengan media audio visual yaitu 69\% (rata-rata kelas) dan 69\% (jumlah siswa yang tuntas belajar). 2) Pada siklus II, kemampuan siswa dalam menulis cerpen yaitu $81 \%$ (rata-rata kelas) dan $100 \%$ (jumlah siswa yang tuntas belajar). Hal ini menunjukkan hasil pembelajaran siswa pada siklus II mengalami peningkatan, yaitu nilai rata-rata klasikal $69 \%$ pada siklus I menjadi $81 \%$ pada siklus II. Jumlah siswa yang tuntas belajar pada siklus I mencapai $69 \%$ menjadi $100 \%$ pada siklus II. 3) Peningkatan kemampuan siswa menggunakan kalimat efektif yaitu pada siklus I mencapai 40,62\% menjadi $100 \%$ pada siklus II , penggunaan tanda baca pada siklus I mencapai $21,87 \%$ menjadi $84,37 \%$ pada siklus II, dan huruf kapital pada siklus I mencapai $34,37 \%$ menjadi $98,87 \%$. 4) Secara kualitatif kemampuan siswa dalam menulis cerpen semakin baik. Pada siklus I siswa kurang aktif dalam belajar, sedangkan pada siklus II siswa sudah menunjukkan keaktifan dan lebih termotivasi dalam belajar, dengan beberapa upaya yang dilakukan yaitu menciptakan suasana belajar yang menyenangkan dan memberikan hadiah kepada siswa yang mendapat nilai tertinggi.

Berdasarkan analisis data dan simpulan, penulis ingin menyarankan beberapa hal sebagai berikut: 1) Dalam proses belajar mengajar hendaknya guru menggunakan media dan metode belajar yang bervarasi agar dapat meningkatkan motivasi dan prestasi belajar siswa misalnya dengan menggunakan media audio visual, karena kreatifitas dan motivasi guru sangat berperan dalam membangun kemampuan siswa dalam proses pembelajaran. 2) Siswa diharapkan lebih menerapkan kaidah penulisan tanda baca, huruf kapital, dan penggunaan kalimat efektif dalam karangan yang dibuat dengan lebih baik yaitu dengan membiasakan penggunaannya dalam menulis. 3) Guru diharapkan terus melatih siswa dalam menulis khususnya cerpen agar kemampuan menulis siswa dapat ditingkatkan lagi.

\section{DAFTAR PUSTAKA}

Akhdiah, Sabarti, dkk. 1996/1997. Menulis. Jakarta: Departemen Pendidikan dan Kebudayaan.

Arianti. 2007. "Meningkatkan Kemampuan Siswa Menulis Deskripsi Arikunto, Suharsmimi. 2006. Prosedur Penelitian suatu Pendekatan Praktis. Jakarta: PT Rineke Cipta.

Arsyad, Azhar. 2007. Media Pembelajaran. Jakarta: PT Raja Grafindo Persada.

Febrina Arianti, Eka. 2007. "Meningkatkan Kemampuan Membuat Paragraf.

Keraf ,Gorys. 2001. Komposisi . Semarang : Nusa Indah.
Mayasari, Shintani. 2006. "Pengaruh Penggunaan Media Audio Visual Roestiyah, N.K. 2001. Strategi Belajar Mengajar. Jakarta: PT Rineke Cipta.

Rohani, Ahmad. 1997. Media Instruksional Edukatif. Jakarta: PT Rineka Cipta.

Sadiman, Arief S. dkk. 2007. Media Pendidikan: Pengertian, Pengembangan

Pemanfaatannya. Jakarta: PT. Raja Grafindo Persada.

Subana dan Sunarti. Tanpa Tahun. St Belajar Mengajar Bahasa Indonesia; Berbagai Pendekatan, Metode Teknik dan 
Media Pengajaran. Bandung:Pustaka Setia.

Sudjana, Nana \& Ahmad Rivai. 2005. Media Pengajaran. Bandung: Sinar Baru Algesindo.

Suriamiharja, Agus(dkk). 1996. Petunjuk Praktis Menulis. Jakarta: Departemen Pendidikan dan Kebudayaan.
Suryaningsih. 2007. "Meningkatkan Kemampuan Menulis Paragraf Induktif dan.

Tarigan, Henri Guntur.1994. Menulis Sebagai Suatu Keterampilan Berbahasa. Bandung:Angkasa.

Zulfahnur. Z.F, dkk. 1996. Teori Sastra. Jakarta: Departemen Pendidikan dan Kebudayaan. 